\section{"NEVER-THE-LESS, I WAS ACCEPTED."}

Dr. Lois Bing wrote this hashtag-worthy phrase in a 1999 letter to the Archives staff recounting her successful application to the Ohio State University's School of Optometry, despite a lessthan-encouraging interview with the program's director. As these artifacts demonstrate, Dr. Bing approached this and all other challenges with equal parts persistence, excellence, and wit-traits she held in common with many of the women profiled in the this issue of Hindsight.

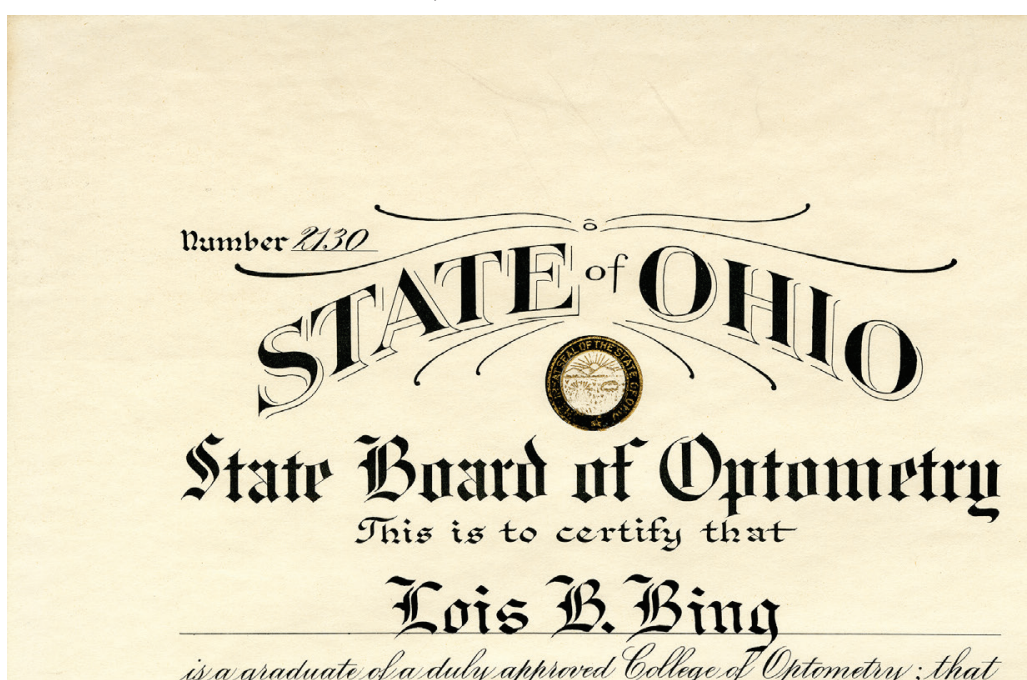
is a graduate of a duly appioved Gollege of Eptometiy; that he has given piosf thioughexamination that he has the neo essaing piofessional ability sequired by law; and has othorwisemet tho sequirements of the statutes for admission to the practice of 6 Optometry so in the State of Chio.

Treretore, bynitue of the powevimested in this Boand by the Segislature of Chio ure have this day auvaded to him this witificate authonizing him to practice Optometry in this state, subject to the goveining statutes, and

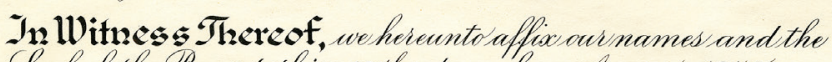
Seabof the Boaid this 15 the day of Auguest, 1915.
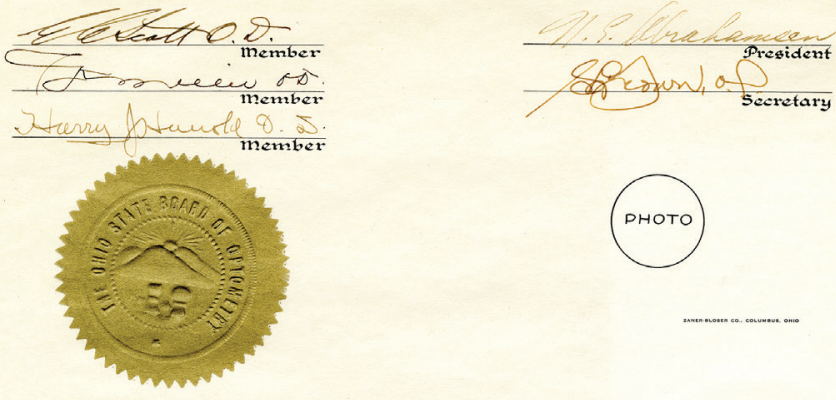

Pronouns matter! Figure 1. Dr. Bing's original certificate of licensure, issued by the Ohio State Board of Optometry in 1948 referred to her as "him" and "he." Figure 2.In the letter she sent to the Archives with her donation, she says she "kept after" the members of the Board to re-issue her license with the correct pronouns. After several years of her bemused needling, the board relented. Images courtesy The Archives \& Museum of Optometry, MSS 501.4.12, Lois Bing Papers..

\section{2}

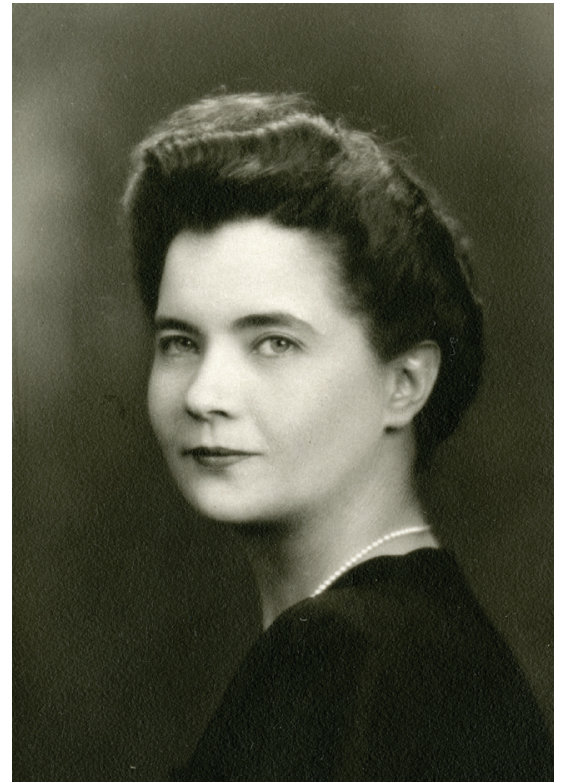

Figure 3. Lois Bing, O.D., circa 1950. Image courtesy The Archives \& Museum of Optometry, MSS 501.4.12, Lois Bing Papers
DR. LOIS B. BING

VISION THERAPY

7054 WEST 130 TH ST. BOX 30243 CLEVELAND, OHIO 441300243 PHONE (216) 845-5210

At the time of my husband's death in 1945 I was president of the women's Auxiliary to the A.O.A. and very much involved in optometry. My husband had been president of the ohio optometric Association and had just served as chaiman of the Resolutions committee of the A.O.A. My family and close friends urged me to go back to school to study to be an optometrist.

When I conferred with the Dean of the college of optometry I was told that they were not anxious to accept women students. Their experience had been that most often women got married and did not contimue to practice optometry. They felt their time was wasted in training women. Never-the-less I was accepted.

Upon graduating and taking the onio state Board of optometry examination I received this certificate of licensure which as you see referred to me as "him" or "he".

I kept after the members of the State Board of Optometry for several years before they finally gave me a new certificate of licensure referring to me as "her" or "she". I teased the Board of optometry saying: "you are confusing my patients. They think I am a she."

Now as you know half of the students are women. 